\title{
Hepatic encephalopathy therapy in the '90s
}

$\mathrm{F}$ OR SEVERAL DECADES NOW, A TIGHT RELATIONSHIP BETWEEN nitrogen metabolism and the presence of hepatic encephalopathy has been accepted, but the responsible mechanism is unknown. Encephalopathy may be induced by oral administration of ammonium salts as well as by dietary nitrogen, mainly in the form of protein. Protein restriction is now the cornerstone of treatment of hepatic encephalopathy. There is a difference between the type of protein and the degree and risk of encephalopathy. The worst offender appears to be animal proteins; substitution of these with vegetable proteins has led to amelioration or reversal of encephalopathy. It is known, for instance, that a milk and cheese diet is less likely to produce coma than an equal amount of protein from animal sources. This likely is related to the amino acid content of milk proteins (rich in branch-chain amino acids), which appear to improve mental status examinations, and which may not provoke encephalopathy in patients with impending coma. Studies originally have focused on the objective measurements of hepatic encephalopathy by electroencephalogram and cytometric testing. Recently, attention has been on nitrogen balance. In all these parameters, substitution of animal protein by vegetable protein appears to be beneficial.

In the midpart of this century, a high protein diet ( $140 \mathrm{~g}$ daily) was the recommended treatment. A high carbohydrate intake was also stressed. Subsequently, several case reports documented that when protein was withdrawn and carbohydrate intake was maintained, patients appeared to improve, raising the notion that restrictive protein intake may be as beneficial as high carbohydrate intake. Summerskill and colleagues in the mid-1950s firmly established protein restriction as a major therapeutic advance in the management of these patients. Fifty-three of 63 patients studied had hepatic cirrhosis associated with chronic excessive alcohol intake. In these patients, the prognosis was poor when jaundice, ascites and coma were present. It was quickly noted that hepatic coma precipitated by reversible events responded better than coma related to progressive, underlying liver disease. Chances of survival became progressively less when the neurological signs of hepatic encephalopathy persisted after more than a week of therapy. Additional treatment with broad-spectrum antibiotics was a favoured option. Shortly thereafter, nonabsorbable antibiotics, particularly neomycin, became the favoured therapy. However, because there is some absorption of oral neomycin, occasionally irreversible side effects occur.

In the late ' 60 s, management of hepatic encephalopathy was improved by the introduction of lactulose. This synthetic disaccharide (1,4-galactosidofructose) is not hydrolyzed in the upper intestinal tract and is not absorbed in the lower bowel. It is metabolized by luminal bacteria producing lactic, acetic and formic acids, and significantly acidifies the lumen, an effect that may alter the absorptive characteristics of ammonia in particular, with resultant less absorption. Lactulose is the treatment of choice in hepatic encephalopathy; it has effectively displaced neomycin because it was found to be as effective and less toxic. In one study to maintain double-blindness, sorbitol was used to mimic the sweetness of lactulose. In the neomy-

Gastroenterology in the $90 \mathrm{~s}$ is a series of short articles addressing topical, controversial issues in the treatment of gastrointestinal disorders. The series is made possible through an educational grant from Astra Pharma Inc cin-sorbitol group, there was also a significant drop in stool $\mathrm{pH}$, but it was impossible to dissect out the effects of neomycin from sorbitol. No further studies are available to clarify this point.

More recently, lactitol has been used, particularly in Europe, rather than lactulose as the favoured carbohydrate. It is not yet available in North America.

When should protein restriction be introduced? What are the recommended sources? How much should be given? Malnutrition is often a prominent feature in the most common cause of end-stage liver disease in North America due to alcohol. In patients who have normal mental status, it is important to maintain a high protein intake, at least $1.5 \mathrm{~g} / \mathrm{kg}$ body weight/day, to reestablish nitrogen balance and to improve the serum levels of albumin where possible. When encephalopathy is recognized, dietary protein restriction should be instituted to $50 \mathrm{~g} /$ day. Lactulose therapy should also be started ( $30 \mathrm{~mL}$ three or four times a day). My preference is to initiate therapy with protein restriction and use vegetable protein. One of the unsung benefits of vegetable protein is increased other components, that is, dietary fibre. These high vegetable diets are known to change nitrogen metabolism by increased incorporation of nitrogen by fecal bacteria, with reduction in urinary urea output and total urinary nitrogen, and a comparable increase in fecal nitrogen.

What can we look forward to in the future? It may be possible to refine further the exact composition of diets. Further studies comparing different vegetable protein diets in this group of patients are awaited with great interest before firm recommendations as to the most ideal diet can be made. Some patients have a lot of problems tolerating the sweetness of the lactulose. It is an expensive medication. Further developments in synthetic disaccharidases, allowing rapid and reproducible colonic bacterial breakdown and producing short-chain fatty acids that acidify the lumen in an inexpensive tablet formulation are anticipated. Perhaps lactitol will fit this mode.

\section{FURTHER READING}

Adams RD, Foley JM. Res Publ A Res Nerv Ment Dis 1953;33:198.

Bianchi GP, et al. J Intern Med 1993;233:385-92.

Bircher J, et al. Lancet 1966; i:890-2.

Conn HO, et al. Gastroenterology 1977;77:573-83.

Davidson CS, Gabuzda GJ. N Engl J Med 1950;243:779-88.

De Bruijn KM, et al. Gut 1983;24:53-60.

Elkington SG, et al. N Engl J Med 1969;281:408-12.

Fenton JCB, et al. Lancet 1966;i:164-6.

Greenberger NJ, et al. Am J Dig Dis 1977;22:845-55.

Keshavarzian A, et al. Am J Gastroenterol 1984;79:945-9.

MacDermott WV, et al. Ann Surg 1954;140:539.

Patek AJ, et al. JAMA 1948;138:543-9.

Philips GB, et al. N Engl J Med 1952;247:239.

Schwartz R, et al. N Engl J Med 1954;251:685-9.

Shaw S, et al. Am J Clin Nutr 1983;38:59-63.

Sherlock S, et al. Lancet 1954;ii:453.

Snell AM, Butt HR. Tr A Am Physicians 1941;56:321-9.

Summerskill WHJ, et al. Am J Med 1957;22:59-75.

Uribe M, et al. Gastroenterology 1985;88:901-7.

Uribe M, et al. Dig Dis Sci 1982;27:1109-16.

Weber FL, et al. Gastroenterology 1985;89:538-44.

CN Williams, MD, FRCPC Halifax, Nova Scotia 


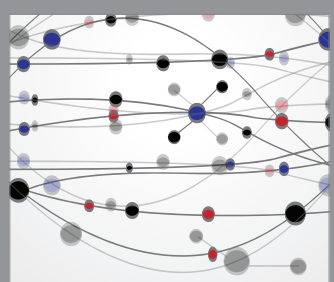

The Scientific World Journal
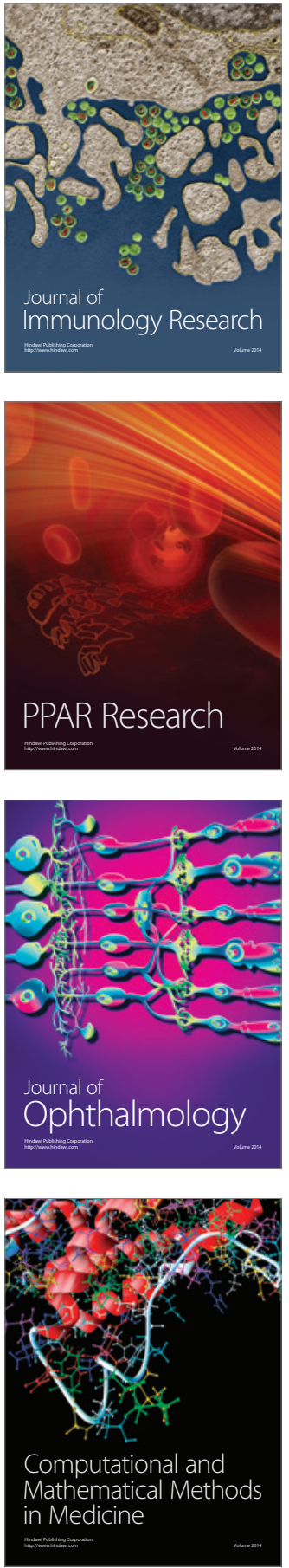

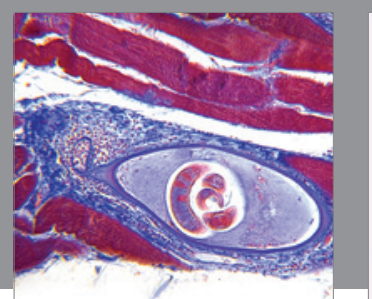

Gastroenterology Research and Practice

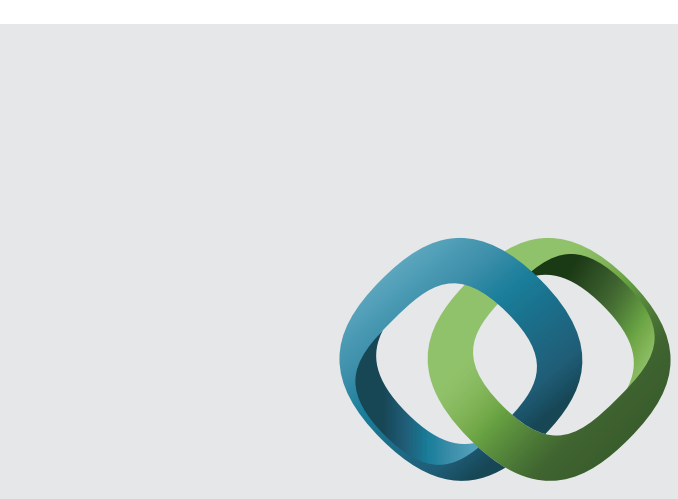

\section{Hindawi}

Submit your manuscripts at

http://www.hindawi.com
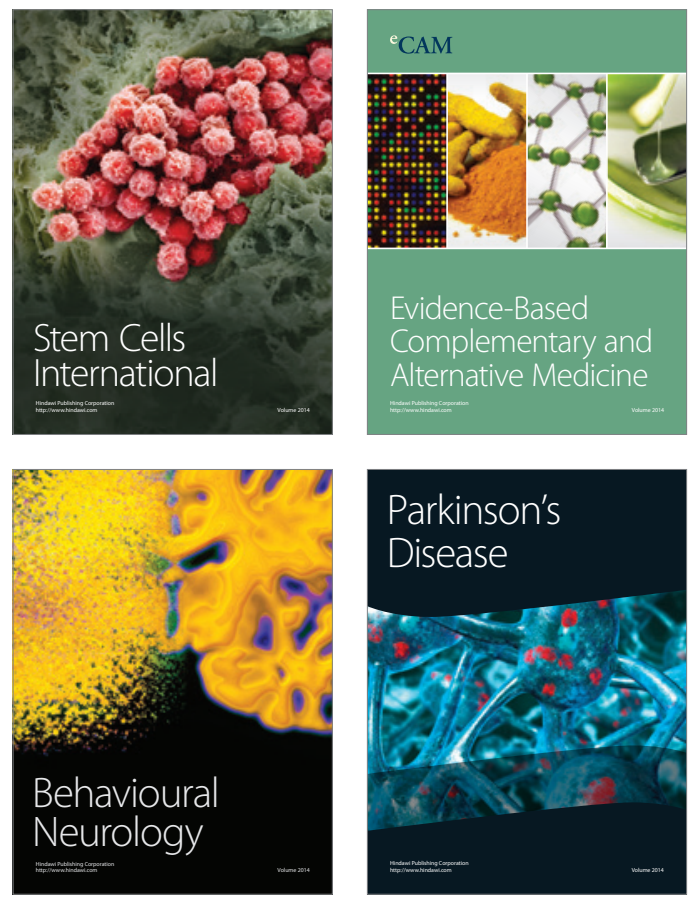
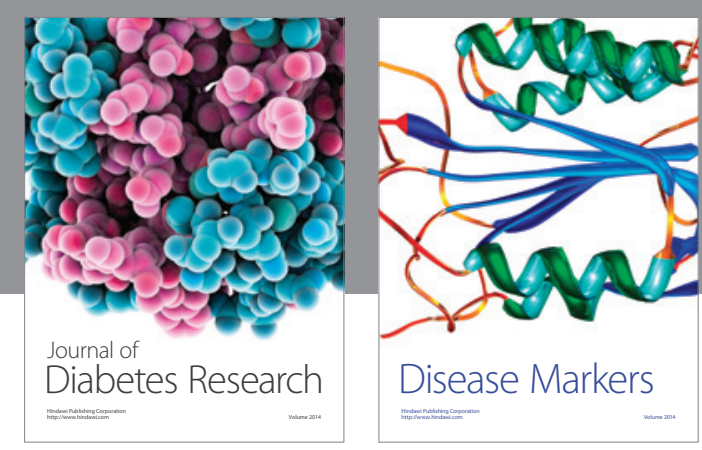

Disease Markers
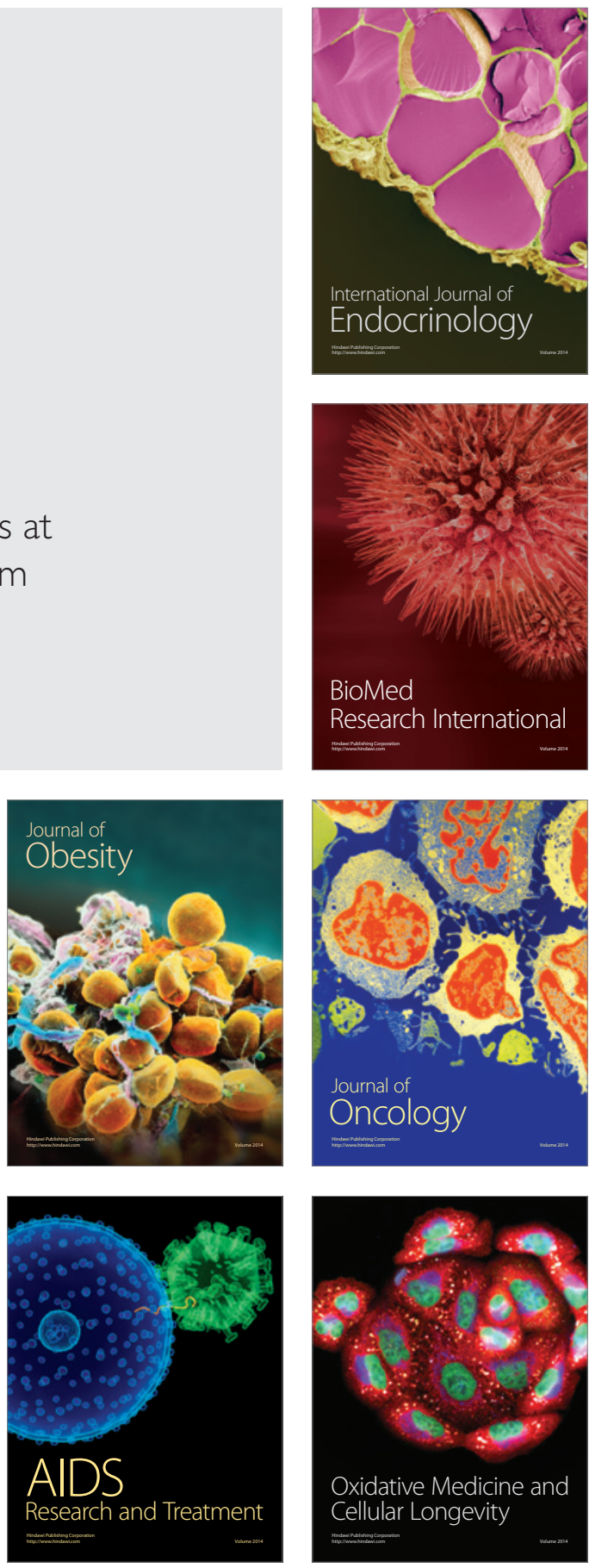